FACTA UNIVERSITATIS

Series: Physical Education and Sport, Vol. 16, No 2, 2018, pp. 399 - 410

https://doi.org/10.22190/FUPES171215036A

Review article

\title{
THE FACTORS WHICH INFLUENCE THE OCCURRENCE AND PREVALENCE OF FLAT FEET AMONG PRESCHOOL CHILDREN
}

\author{
UDC 613.825.01
}

\author{
Ivana Anđelković1, Slađan Karaleić2 ${ }^{2}$ Vesko Milenković \\ Ljubiša Lilić2 , Branimir Mekić², Rade Stefanovićc \\ ${ }^{1}$ Faculty of Sport and Physical Education, University of Niš, Niš, Serbia \\ ${ }^{2}$ Faculty for Sport and Physical Education in Leposavić, \\ University of Priština, Leposavić, Serbia
}

\begin{abstract}
The foot represents one of the most complicated anatomical segments of the human body. As, phylogenetically speaking, the youngest organ of "homo erectus", the foot is subject to various disorders and deformities. Flat feet (pes planus) represent one of the most frequent deformities of the lower extremities, with a loss of the normal physiological arches. The subject matter of this research is the prevalence of flat feet among preschool children. The aim of this review paper is to identify and sum up the relevant literature on the frequency of pes planus and the factors of occurrence among preschool children. The analyzed papers have all been published in the period from 2000 to 2016. The research results indicate an increased prevalence of flat feet approximately around the age of 3, and a decrease around the age of 6. The main factor of occurrence is usually obesity, and the deformity occurs more frequently among boys. The conclusion is that by controlling body mass, daily physical activity, as well as an adequate corrective treatment, we might decrease the prevalence of flat feet deformities among preschool children.
\end{abstract}

Key words: Flat feet, deformity, obesity, preschool age

\section{INTRODUCTION}

One of the most important periods in the life of a child is the preschool age, since that is the time when either good or bad foundations are laid which later help form a healthy

Received December 15, 2017 / Accepted September 24, 2018

Corresponding author: Ivana Anđelković

University of Priština, Faculty for Sport and Physical Education in Leposavić, Dositeja Obradovića bb, 38218 Leposavić, Serbia

Phone: +38128 84700•E-Mail: ivana.andjelkovic.ks@gmail.com 
human being (Karković, 1998). It is very important to inform children about the importance of physical activity which has a great impact on the healthy lifestyle of young people. It contributes to the development and maintenance of human abilities during the course of one's life. Physical activity plays a great role in achieving the optimal state of health, and at the same time has an effect on the decrease in the risk of the occurrence of various illnesses, which is why it is important to create the habit for daily physical exercise at the earliest age (Živković, 2009).

The foot represents one of the most complicated anatomic segments of the human body. There are 26 bones and 32 joints in the foot which along with the tendons and neurovascular elements provide two important functions of the foot, which include: standing (static foot structure) and walking, running and jumping (dynamic foot function) (Radisavljević, 2001).

Deformities of the foot have a deciding influence on the functional state of the locomotor apparatus, especially of the lower extremities. The foot bears the greatest burden both in the case of the static and dynamic function of the locomotor apparatus. Flat feet is a frequent deformity among preschool children (Pfeiffer, Kotz, Ledl, Hauser, \& Sluga 2006), and is characterized by the loss of normal, physiological arches of the feet. It can be innate or acquired over time. As a rule, among children aged 2 or 3, sometimes a "false pes planus" occurs, as a result of the accumulation of subcutaneous fat tissue.

Foot deformity is a consequence of the modern way of life, such as excessive use of transportation devices, a sedentary lifestyle, the selection of footwear and how clean we keep our footwear (Živković \& Karaleić, 2014).

The causes of the occurrence and prevalence of postural disorders among children are various: obesity (Milošević, Obradović, \& Srdić, 2007a, Milošević, Obradović, \& Srdić, 2007b), a low nutritional status (Protić-Gava, 2008), insufficient physical activity which further decreases when a child starts school (Sallis, Prochaska, \& Taylor, 2000), which later in life represents a serious problem. For example, it can affect motor manifestation, and especially explosive leg strength (Aleksandrović \& Kottaras, 2015). The main obstacles to maintaining physical activity at the optimal level include a lack of time, the absence of energy, interest or motivation (Maksimović \& Milošević, 2008).

The subject matter of this research is to determine the factors of the occurrence and prevalence of flat feet among preschool children. Thus, this systematic overview of the current literature had as its aim to identify and sum up the relevant data on the prevalence of flat feet among preschool children, as well as the factors of their occurrence.

To realize the set goal, the following tasks were carried out:

- a search of electronic databases;

- an overview and translation of the compiled literature;

- an analysis of the research results.

\section{METHODS}

\section{The source of the data and the research strategy}

To survey the existing literature, the following electronic bases were used: PubMed, Google Scholar, EBSCO from 2000 to 2016. The survey was carried out based on the following key words (individually or in combination): flat feet, deformity, obesity, 
preschool age. The search strategy was modified for each electronic database, where possible, with the aim of increasing sensitivity. All of the titles and abstracts were reviewed for potential papers which will be included in the systematic overview. In addition, we reviewed the lists of references of previously reviewed original studies as well.

The literature review was performed by one author (IA). Relevant studies were obtained following a detailed overview, if they met the criteria of inclusion, including original research, participants aged 6 .

The research papers which met the set criteria were then analyzed and presented based on the following parameters: the references (the author and year of publication of the research), the sample of participants (their overall number, age), the status of the feet, measurement technique, corrective treatment and research results.

The systematic review of the papers presented here is based on the methodological recommendations and in accordance with the Preferred Reporting Items for Systematic Reviews and Meta-Analyses - PRISMA consensus (Moher, Liberati, Tetzlaff, \& Altman, 2009). The selection of data was performed following the protocol of the Cochrane Consumers and Communication Review Group's data extraction. The selection and evaluation of the input data was performed by one author, for the purposes of precision and completion. All of the included papers were reviewed as a whole, so as to introduce the necessary data.

\section{The criteria for inclusion}

- The type of study: controlled randomized and non-randomized studies were reviewed and included in further analysis, while non-controlled and transversal studies were excluded. Papers published in English and Serbian were included in the study;

- The sample of participants: the included participants were preschool children aged 6;

- The type of intervention: studies which determine the factors of occurrence and prevalence of flat feet among preschool children;

- The type of obtained results: the primary obtained results needed for a systematic overview were the prevalence of flat feet and the percentage of occurrence, as well as whether there are any differences after the corrective treatment (if there was one).

\section{The criteria for exclusion}

- Studies written in a language other than English and Serbian;

- Duplicates;

- Studies including participants older than 7.

\section{RESULTS}

Following a general search of the databases we identified 128 potential papers and three additional ones based on their references. Following the removal of duplicates and an overview of the titles and abstracts, 97 papers were left. The remaining papers were perused in detail. Based on the criteria for inclusion, an additional 13 papers did not meet the requirements for further processing. By overviewing the entire texts based on the 
criteria for inclusion, 20 studies remained which met the predefined criteria and were included in the systematic overview. The detailed review of the selection of papers and their inclusion can be found in Figure 1.
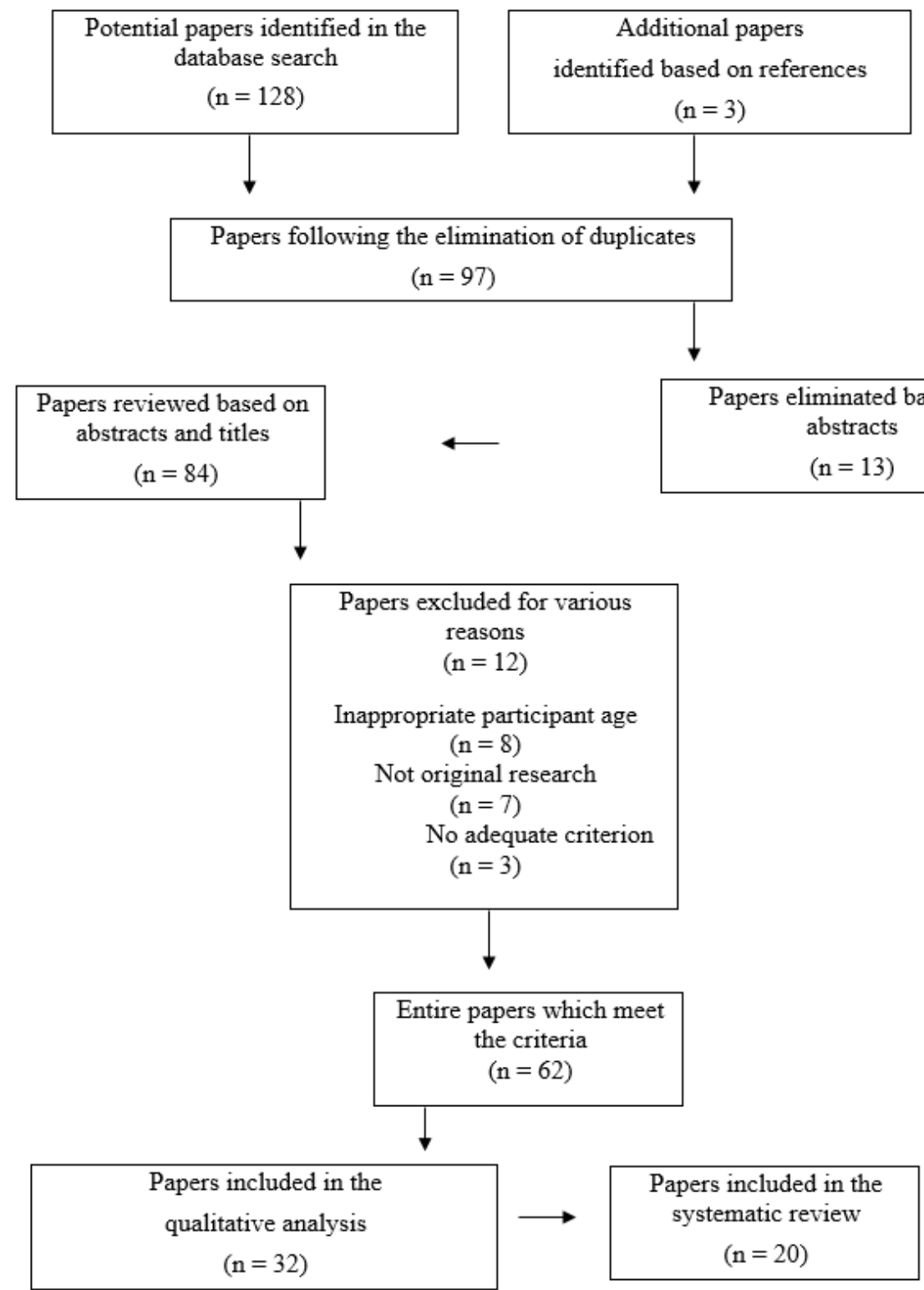

Fig 1. A review of the process of compiling adequate papers based on predefined criteria 
Table 1 An overview of the research and conditions

\begin{tabular}{|c|c|c|c|c|}
\hline $\begin{array}{c}\text { First author and } \\
\text { year of } \\
\text { publication }\end{array}$ & $\begin{array}{l}\text { Number of } \\
\text { participants }\end{array}$ & $\begin{array}{l}\text { Age of the } \\
\text { participants }\end{array}$ & $\begin{array}{l}\text { Status of the feet, } \\
\text { measurement } \\
\text { technique, corrective } \\
\text { treatment }\end{array}$ & Results \\
\hline $\begin{array}{l}\text { Pfeiffer et al. } \\
\text { (2006) }\end{array}$ & $\begin{array}{l}\mathrm{N}-835 \\
\mathrm{M}-424 \\
\mathrm{~F}-411\end{array}$ & $3-6$ & $\begin{array}{l}\text { Flexible flat feet } 44 \% \\
\text { pathologically (rigid) } \\
\text { flat foot less than } 1 \%\end{array}$ & $\begin{array}{l}\text { The presence of flat feet } \\
\text { significantly decreases with age } \\
\text { (three-year-olds } 54 \% \text { and six-year- } \\
\text { olds } 24 \% \text { ). A significant difference } \\
\text { in the prevalence of flat feet was } \\
\text { noted among obese children (13\%) }\end{array}$ \\
\hline $\begin{array}{c}\text { Mihajlović, } \\
\text { Šolaja, \& } \\
\text { Petrović (2010a) }\end{array}$ & N-557 & $4-7$ & Digital podoscope & $\begin{array}{l}\text { No statistically significant } \\
\text { difference was determined based } \\
\text { on gender, while a difference in } \\
\text { terms of age was determined }\end{array}$ \\
\hline $\begin{array}{c}\text { Mihajlović, } \\
\text { Šolaja, \& } \\
\text { Petrović (2010b) }\end{array}$ & F-272 & $4-7$ & $\begin{array}{l}\text { Computerized digitial } \\
\text { podography } \\
\text { over } 90 \% \text { prevalence } \\
\text { of the } \\
\text { pes transverso planus, } \\
\text { calcaneo valgi and pes } \\
\text { planus deformities }\end{array}$ & $\begin{array}{l}\text { With an increase in age there is a } \\
\text { decrease in the percentage of } \\
\text { prevalence of flat feet }\end{array}$ \\
\hline $\begin{array}{l}\text { Chen et al. } \\
\text { (2011) }\end{array}$ & $\begin{array}{l}\text { N-1598 } \\
\text { M-833 } \\
\text { F-765 }\end{array}$ & $3-6$ & $\begin{array}{l}\text { Normal foot arches } \\
\text { (n-733), unilateral flat } \\
\text { foot (n-266), and both } \\
\quad \text { flat feet (n-599) }\end{array}$ & $\begin{array}{l}\text { A significant decrease in the } \\
\text { presence of flat feet among older } \\
\text { children (from } 54,5 \% \text { among } \\
\text { three-year-olds to } 21 \% \\
\text { among six-year-olds in the third } \\
\text { group) the prevalence of flat feet } \\
\text { increases with the increase in body } \\
\text { weight and is greater among boys }\end{array}$ \\
\hline $\begin{array}{l}\text { Stanišić, } \\
\text { Đorđević, \& } \\
\text { Maksimović } \\
\text { (2014) }\end{array}$ & $\begin{array}{l}\text { N-60 } \\
\text { M-21 } \\
\text { F-39 }\end{array}$ & 6 & $\begin{array}{l}\text { The method of } \\
\text { Napoleon Voljansky } \\
\text { was used to evaluate } \\
\text { the status of the lower } \\
\text { extremities, while the } \\
\text { prevalence of the flat } \\
\text { feet deformity was } \\
\text { evaluated by reading a } \\
\text { plantogram using the } \\
\text { Thompsen method, } \\
\text { with a two-month } \\
\text { corrective treatment } \\
\text { three times a week }\end{array}$ & $\begin{array}{l}\text { By analyzing the measurement of } \\
\text { the status following a two-month } \\
\text { corrective treatment, the } \\
\text { conclusion was reached that the } \\
\text { effect of the work was positive }\end{array}$ \\
\hline $\begin{array}{l}\text { Sonia et al. } \\
\text { (2015) }\end{array}$ & $\begin{array}{l}\text { N-110 } \\
\text { M-71 } \\
\text { F-39 }\end{array}$ & $3-6$ & $\begin{array}{c}21(19,1 \%)- \\
\text { bilateral flat feet } \\
7(6,4 \%)- \\
\text { unilateral flat foot } \\
\text { A clinical method, } \\
\text { reading a plantogram, } \\
\text { flexion tests, rotation } \\
\text { angles in the hip and } \\
\text { knee joint }\end{array}$ & $\begin{array}{c}\text { A negative correlation was } \\
\text { determined between insufficient } \\
\text { external torsion of the tibia and flat } \\
\text { feet }\end{array}$ \\
\hline
\end{tabular}




\begin{tabular}{|c|c|c|c|c|}
\hline $\begin{array}{l}\text { Hsun-Wen et al. } \\
\text { (2012) }\end{array}$ & $\begin{array}{l}\mathrm{N}-44 \\
\mathrm{M}-24 \\
\mathrm{~F}-20\end{array}$ & $2-6$ & $\begin{array}{l}\text { Five groups, } \\
\text { 3D contours of the } \\
\text { feet were measured } \\
\text { using a 3D scanner }\end{array}$ & $\begin{array}{l}\text { A 3D laser scanner represents an } \\
\text { exceptional reference for clinical } \\
\text { study, as well as an index for } \\
\text { distinguishing between types of } \\
\text { deformities }\end{array}$ \\
\hline $\begin{array}{l}\text { Mickle, Cliff, } \\
\text { Munro, Okely, \& } \\
\text { Steele } \\
\text { (2011) }\end{array}$ & $\begin{array}{l}\text { N-33 } \\
\text { M-17 } \\
\text { F-16 }\end{array}$ & $3-5$ & $\begin{array}{l}\text { An insufficiency } \\
\text { clinical method, with } \\
\text { valgus status, a } \\
\text { tension platform, } \\
\text { accelerometer, daily } \\
\text { physical activity, } \\
\text { moderate, light and } \\
\text { sedentary }\end{array}$ & $\begin{array}{l}\text { High pressure on the feet has a } \\
\text { negative correlation with physical } \\
\text { activity } \\
\text { Conclusion: boys more often } \\
\text { prefer their heels and girls their } \\
\text { toes when they walk }\end{array}$ \\
\hline $\begin{array}{l}\text { Ezema, } \\
\text { Abaraogu, \& } \\
\text { Okafor } \\
(2014)\end{array}$ & $\begin{array}{l}\text { N-474 } \\
\text { M-221 } \\
\text { F-253 }\end{array}$ & $6-10$ & $\begin{array}{l}22,4 \% \text { of some form } \\
\text { of flat feet } \\
\text { The Staheli plantar } \\
\text { index (PI) } \\
\text { Transversal overview }\end{array}$ & $\begin{array}{l}\text { In terms of percentages, the } \\
\text { greatest prevalence, of the } \\
\text { disorders could be found among } \\
\text { six-year-olds which decreases later } \\
\text { with age }\end{array}$ \\
\hline $\begin{array}{l}\text { Jimenez-Ormeno, } \\
\text { Aguado, } \\
\text { Delgado-Abellán, } \\
\text { Mecerreyes, \& } \\
\text { Alegre } \\
\text { (2013) }\end{array}$ & $\begin{array}{l}\text { N-1032 } \\
\text { M-497 } \\
\text { F-535 }\end{array}$ & $6-12$ & $\begin{array}{l}\text { Obese, increased and } \\
\text { normal weight, BMI } \\
\text { and a 3D foot scanner, } \\
\text { with an analysis of } \\
\text { each age group }\end{array}$ & $\begin{array}{c}\text { Obesity increases the presence of } \\
\text { foot deformity. Normal-increased } \\
\text { weight }(2,6-9 \%) \text {, normal-obese } \\
(3,9-17,3 \%) \text {, increased- obese } \\
(5,3-7,6 \%)\end{array}$ \\
\hline $\begin{array}{l}\text { Woźniacka, Bac, } \\
\text { Matusik, } \\
\text { Szczygiel, \& } \\
\text { Ciszek (2013) }\end{array}$ & $\begin{array}{l}\text { N-1115 } \\
\text { M-564 } \\
\text { F-551 }\end{array}$ & $3-12$ & $\begin{array}{l}\text { Obese, increased and } \\
\text { normal weight, BMI } \\
\text { and Clark's method } \\
\text { for diagnosing high } \\
\text { arches and flat feet }\end{array}$ & $\begin{array}{l}\text { The greatest prevalence of flat feet } \\
\text { among the ages of } 4-6 \text {. High } \\
\text { arches are most prevalent among } \\
\text { children aged } 8 \text { and } 11 .\end{array}$ \\
\hline $\begin{array}{l}\text { Riddiford- } \\
\text { Harland, Steele, } \\
\text { J.R, \& Baur } \\
\text { (2011a) }\end{array}$ & $\begin{array}{l}\text { N-150 } \\
\text { Norm.-75 } \\
\text { Obes.-75 }\end{array}$ & $6-9$ & $\begin{array}{l}\text { Increased and normal } \\
\text { weight, flat feet and } \\
\text { the thickness of } \\
\text { subcutaneous fat of } \\
\text { the medial arch. } \\
\text { Podography and } \\
\text { ultrasonography. }\end{array}$ & $\begin{array}{l}\text { Fat tissue on the medial arch of the } \\
\text { feet does not influence flat feet, } \\
\text { and is even thicker in mild cases }\end{array}$ \\
\hline $\begin{array}{l}\text { Mickle, Steele, \& } \\
\text { Munro (2008) }\end{array}$ & $\begin{array}{l}\text { N-88 } \\
\text { M-36 } \\
\text { F-52 }\end{array}$ & $3-6$ & $\begin{array}{l}\text { Flat feet and the } \\
\text { thickness of the } \\
\text { subcutaneous fat of } \\
\text { the medial arch among } \\
\text { boys and girls. } \\
\text { Podography and } \\
\text { ultrasonography }\end{array}$ & $\begin{array}{l}\text { The cause of the percentually } \\
\text { greater prevalence of flat feet } \\
\text { among boys is greater fat tissue on } \\
\text { the medial arch of the feet }\end{array}$ \\
\hline $\begin{array}{l}\text { Mauch, Grau, } \\
\text { Krauss, Maiwald, } \\
\text { \& Horstmann } \\
\text { (2008) }\end{array}$ & $\begin{array}{l}\text { N-2887 } \\
\text { M-1450 } \\
\text { F-1437 }\end{array}$ & $2-14$ & $\begin{array}{l}\text { Increased, decreased } \\
\text { and normal weight, } \\
\text { flat feet and the related } \\
\text { typology. 3D scan of } \\
\text { the feet and BMI }\end{array}$ & $\begin{array}{l}\text { Obese children most often have } \\
\text { flat and robust feet, and those with } \\
\text { lower weight, slight and elongated } \\
\text { feet, while children with normal } \\
\text { weight have all types of feet }\end{array}$ \\
\hline
\end{tabular}




\begin{tabular}{|c|c|c|c|c|}
\hline $\begin{array}{l}\text { Mueller, } \\
\text { Carlsohn, } \\
\text { Mueller, Baur, \& } \\
\text { Mayer } \\
\text { (2016) }\end{array}$ & $\begin{array}{c}\text { N-7575 } \\
\text { M-3630 } \\
\text { F-3945 }\end{array}$ & $1-12$ & $\begin{array}{l}\text { Obese, increased and } \\
\text { normal weight, BMI. } \\
\text { The volume, pressure } \\
\text { and speed of the feet } \\
\text { on a treadmill. Each } \\
\text { age category } \\
\text { individually }\end{array}$ & $\begin{array}{l}\text { The speed of the task was equal, } \\
\text { while the volume, pressure and } \\
\text { arch values were greater among } \\
\text { obese children and children with } \\
\text { increased weight compared to } \\
\text { children with normal weight }\end{array}$ \\
\hline $\begin{array}{c}\text { Mickle, Steele, \& } \\
\text { Munro } \\
\text { (2006a) }\end{array}$ & $\begin{array}{c}\text { N-38 } \\
\text { Norm.-19 } \\
\text { Obes.-19 }\end{array}$ & $3-6$ & $\begin{array}{l}19 \text { obese children and } \\
19 \text { children with } \\
\text { normal weight, } \\
\text { ultrasound } \\
\text { diagnostics, fat tissue } \\
\text { on the medial arch }\end{array}$ & $\begin{array}{l}\text { The thickness of fat tissue did not } \\
\text { show any statistically significant } \\
\text { differences, while flat feet are more } \\
\text { prevalent among obese children } \\
\text { and children with increased weight }\end{array}$ \\
\hline $\begin{array}{l}\text { Chen, Chung, \& } \\
\text { Wang } \\
\text { (2009) }\end{array}$ & $\begin{array}{l}\text { N-1034 } \\
\text { M-549 } \\
\text { F-475 }\end{array}$ & $5-13$ & $\begin{array}{l}\text { Normal weight, } \\
\text { increased weight and } \\
\text { obesity, flat feet, 3D } \\
\text { probe and digital tape, } \\
\text { overview of the status }\end{array}$ & $\begin{array}{l}\text { The prevalence of flat feet is } \\
\text { greater among boys ( } 35-20 \%) \text {, } \\
\text { with normal weight } 27 \% \text {, with } \\
\text { increased weight } 31 \% \text { and obesity } \\
56 \% \text {. The percentage decreases } \\
\text { with age }\end{array}$ \\
\hline $\begin{array}{c}\text { Echarri \& Forriol } \\
\text { (2003) }\end{array}$ & $\begin{array}{l}\text { N-1851 } \\
\text { M-945 } \\
\text { F-906 }\end{array}$ & $3-12$ & $\begin{array}{l}\text { Flat feet, the } \\
\text { Chippaux-Smirak } \\
\text { index, Staheli index, } \\
\text { Clark's angle for } \\
\text { comparing children } \\
\text { from urban and rural } \\
\text { environments - }\end{array}$ & $\begin{array}{l}\text { The greatest prevalence is among } \\
\text { children aged 3-4 with a decrease } \\
\text { among older children. A greater } \\
\text { percentage of flat feet among boys } \\
\text { and generally those living in an } \\
\text { urban environment }\end{array}$ \\
\hline $\begin{array}{l}\text { Vergara-Amador, } \\
\text { Sanchez, Posada, } \\
\text { Molano, \& } \\
\text { Guevara (2012) }\end{array}$ & $\begin{array}{c}\text { N-940 } \\
\text { Bogota 60\% } \\
\text { Barranquilla } \\
40 \%\end{array}$ & $3-10$ & $\begin{array}{l}\text { One of the factors of } \\
\text { the prevalence of flat } \\
\text { feet but was not } \\
\text { treated. Flat feet in } \\
\text { two different } \\
\text { geographic areas, } \\
\text { plantography with the } \\
\text { Denis method }\end{array}$ & $\begin{array}{l}\text { A general prevalence of } 15,74 \% \\
(20,8 \text { and } 7,9 \%) \text {. A general } \\
\text { prevalence among children from } \\
\text { the ages of } 3 \text { to } 5 \text { is } 30,9(38,3 \text { and } \\
17,3 \%) \text { while among children aged } \\
6-7 \text { is } 11,3 \%(17,2-1,5 \%) \text {. The } \\
\text { percentage decreases with age }\end{array}$ \\
\hline $\begin{array}{l}\text { Mickle, Steele, \& } \\
\text { Munro (2006b) }\end{array}$ & $\mathrm{N}-34$ & $\begin{array}{l}\text { Obese } \\
4,4 \pm 08 \text { yrs. } \\
\text { Norm. } \\
\text { weight. } \\
4,4 \pm 07 \text { yrs. }\end{array}$ & $\begin{array}{l}\text { Obese and normal } \\
\text { weight based on BMI. } \\
\text { The pressure of the } \\
\text { feet on the tension } \\
\text { platform while } \\
\text { walking }\end{array}$ & $\begin{array}{l}\text { There is a significantly greater } \\
\text { contact surface and force of } \\
\text { pressure on the tension plate } \\
\text { among obese individuals. The } \\
\text { pressure point at the level of the } \\
\text { medial arch was increased and } \\
\text { indicated flat feet }\end{array}$ \\
\hline
\end{tabular}

\section{DISCUSSION}

The overall number of participants included in this analysis was 20727 children. The largest sample was found in the paper written by Mueller et al. (2016), 7575 participants, and the smallest number in the paper by Mickle, Cliff, Munro, Okely, \& Steele (2011), 33 participants. Nineteen studies included participants of both genders (Pfeiffer et al., 2006; Mihajlović, Šolaja, \& Petrović, 2010; Chen, Chung, \& Wang, 2009; Chen, et al. 2011; Mickle et al., 2011, Mickle, Steele, \& Munro, 2006b; Hsun-Wen et al., 2012; Stanišić, Đorđević, \& Maksimović, 2014; Sonia et al., 2015; Ezema, Abaraogu, \& Okafor, 2014; 
Jiménez-Ormeño, Aguado, Delgado-Abellán, Mecerreyes, \& Alegre, 2013; Woźniacka, Bac, Matusik, Szczygieł, \& Ciszek, 2013; Riddiford-Harland, Steele, \& Baur, 2011a; Mauch, Grau, Krauss, I., Maiwald, \& Horstmann, 2008; Mueller, Carlsohn, Mueller, Baur, \& Mayer, 2016; Echarri \& Forriol, 2003; Vergara-Amador, Sanchez, Posada, Molano, \& Guevara, 2012). One study included female participants (Mihajlović, Smajić, $\&$ Sente, 2010).

The subject of the research are papers focused on the population of preschool children (Pfeiffer et al., Chen et al., Sonia et al., Mickle, Steele, \& Munro, 3-6; Mihajlović et al., 4-7; Stanišić et al., 6; Hsun-Wen et al., 2-6; Mickle et al., 3-5). However, some of the authors also included the population of children of a broader age range (Ezema et al., 610; Jiménez-Ormeno et al., 6-12; Woźniacka et al., Echarri \& Forriol, 3-12; RiddifordHarland et al., 3-9; Chen et al., 5-13; Vergara-Amador et al., 3-10; Mauch et al., Mueller et al., 2-14 and 1-12). The only authors who included children under the age of 3 were Mauch et al., (2008) \& Mueller et al., (2016) which is interesting because of the opinion of the researchers that a child's foot up to the age of 3 is mostly without arches (longitudinal and transversal, anterior and lateral), which was why it was unnecessary to measures such feet (as this is a physiologically normal state). However, by using more modern measuring instruments, we might assume that some form of flat feet will emerge, that is, deformities in the static and dynamic features of the feet.

The main division of feet deformities was into flexible (functional) and rigid (structural) feet. Most of the authors in the analyzed papers measured and focused only on deformities of the longitudinal arch of the foot. Some authors, in addition to determining the status of the longitudinal arch of the foot, also analyzed the pes transverse planus (Mihajlović, Smajić, \& Sente, 2010), feet insufficiency with the valgus position (Mickle et al., 2011; Mihajlović, Smajić, \& Sente, 2010; Ezema et al., 2014), the state of the lower leg and hip and knee joint (Stanišić et al., 2014; Sonia et al., 2015). "Hollow feet" were analyzed by Woźniacka et al. (2013) who obtained results which are contrary to one of the rules of flat feet, which is that with age the percentage of children with flat feet decreases, as in this case an increase in the prevalence of pes cavus was noted among older children. One of the questions which scientists and researchers asked is whether the fat tissue on the arch of the foot has a real influence on the evaluation of the status of the arches of the feet. Some of the authors tried to answer this question in their research, and obtained various results (Mickle et al., 2006a, 2008; Riddiford-Harland et al., 2011a). Another one of the various means of approaching the evaluation of the arches of the feet is also the analysis of the status of one or both feet. Authors who studied the problem of a single flat foot or two flat feet were Chen et al. (2011) and Sonia et al. (2015).

It was already mentioned that the evaluation of the status of the feet improved with the implementation of new instruments and techniques, which brought progress in the diagnosis of disorders and deformities, as well as in their prevention and correction. In this survey paper we came across various techniques and instruments used to evaluate the status of the feet. One of the oldest and generally accepted and implemented methods for the evaluation of the postural status of feet is the method developed by Napoleon Voljansky which was implemented in the work of Stanišić et al. (2014) in combination with plantography, read using the Thompsen method, while Clark's method of reading plantograms was applied by Wozniack et al., and the Denis method by Vergara-Amador et al. (2012). Two researchers implemented the Staheli plantar index to evaluate the state 
of the arches of the feet (Ezema et al., 2014 and Echarri and Forriol, 2003). Most of the authors relied on computerized digital podography (Mihajlović et al., 2010, 2010; Riddiford-Harland et al., 2011; Pfeiffer et al., 2006; Mickle et al., 2006a, 2006b; Chen et al., 2009) which had for a number of years replaced the outdated (but still effective) method of reading foot imprints made on paper. Two of the most modern methods for the evaluation of the status of the arches of the feet were provided by the 3D scanner and the mobile tension treadmill. The 3D scanner was used by the authors Chen et al. (2009), Mauch et al. (2008), Hsun-Wen et al. (2012) and Jimenez-Ormeno et al. (2013) who obtained results which were of a broader scope since the foot is analyzed in 3 dimensions so that one scan can note all the deformities of the foot. The advantage of digital plantography which is read on a mobile tension track is great because the arches of the feet are studied in motion, so that at the same time it is possible to evaluate the height of the arch, the pressure on the platform and the pressure points, as well as the angle of the step (Mickle et al., 2006, 2011; Chen al., 2009; Mueller et al., 2016). To measure the amount of fat tissue of the plantar part of the foot most of the authors used the Ultrasonographic probe which is used to precisely determine the thickness of the fat tissue along the vertical arch of the foot among children (Mickle et al., 2006, 2008 and Riddiford-Harland et al., 2011).

The corrective treatment was implemented in the work of the authors Stanišić et al. (2014) over a two-month period, with a frequency of three times a week, and even after a short period of time working with children aged 6 , positive results were noted at the final measurement.

According to the results analyzed in the papers most of the authors concluded that one of the main factors of the prevalence of flat feet was age. Pfeiffer et al. (2006) concluded that the prevalence of flat feet among the ages of 3 to 6 decreases from $54 \%$ to $24 \%$, while in the work of Chen et al. (2009) for the same age group the difference was from $54,5 \%$ to $21 \%$. Mihajlović, Smajić, \& Sente (2010b), working on a sample of 4 to 7 -yearolds reached the same conclusion without precise data, while Ezema et al. (2014) obtained the same results on a group of children aged 6-10. Also, in the study of Wozniacka et al. (2013), the results are similar because they concluded that the prevalence is greatest among children aged 4-6 in a sample of participants aged 3 to 12 . Echarri et al. (2003), on a sample of participants aged 3-12, obtained results which indicate a tendency of decrease in the prevalence of flat feet with an increase in age.

In a study which differs from others because it evaluated the status of the feet in geographically varied areas, Vergara-Amador et al. (2012) obtained results which indicate the aforementioned tendency of a decrease with age (38,3\% and 17,3\% among 3-5 year olds and $17,2 \%$ and $1,5 \%$ among children aged 6 to 7 ) and differences in the prevalence of flat feet among children who live in mountainous and seaside areas (20,8\% to $7,9 \%)$.

Another very significant cause of the onset of flat feet is increased weight and obesity among children. Pfeiffer et al. (2006) obtained results that the prevalence among obese children is $13 \%$ greater, while Chen et al. (2011) concluded that the prevalence increased with the increase in body weight. The authors Jiménez-Ormeno et al. (2013) divided the sample of participants into children with normal and increased weight and obese children and concluded that the excess of body weight increases the prevalence of flat feet in the following ratio: normal-overweight 2,6\%-9\%, normal weight-obese 3,9\%-17,3\% and overweight-obese $5,3 \%-7,6 \%$. The difference between participants with normal weight, 
overweight and obese participants was determined by Chen et al. (2009) with a value of $27 \%-31 \%-56 \%$. Mickle et al. (2006) by using the mobile tension treadmill came to the conclusion that the contact surface and pressure force is greater among obese individuals. Mauch et al. (2008) by using a 3D scanner carried out foot typology on a sample of children aged 2-14 with a division of the sample into participants with normal weight, reduced weight and obese participants, and came to the conclusion that obese children usually have flat and robust feet, children with decreased weight slender and long, while children with normal weight have all types of feet.

In addition to these two significant factors of the prevalence of flat feet, there is also the factor of gender. Chen et al. $(2009,2011)$ in their work present results which indicate the prevalence of flat feet among boys, especially obese ones, in the ratio of 35\%-20\%, while the authors Echarri \& Forriol (2003) by agreeing with this conclusion add that the percentage is greater among children in an urban environment. Mihajlović, Šolaja, \& Petrović (2010) do not agree with the presented results, since in their studies they did not reach a statistically significant difference between the genders.

Mickle et al. (2006) came to the conclusion that high pressure on the feet negatively correlates with physical activity, and that boys step more on their heels and girls on their toes.

The presence of fat tissue on the sole part of the feet is a physiological occurrence and children are born with it. Over age the tissue disappears, and the arches of the feet are more pronounced. The authors Mickle et al. $(2006,2008)$ came to the results which indicate that there are no statistically significant differences between the thickness of fat tissue among obese children and children with normal weight, and that the prevalence among boys is greater due to the fat tissue on the medial arches of their feet. However, Riddiford-Harland et al. (2011b) consider that fat tissue does not lead to flat feet and that it is even thicker in the case of mild flat feet.

\section{CONCLUSION}

Flat feet are a frequent problem among children and the most frequent reason for visiting a physician, both because of the deformity itself, and because of the problems that accompany this state. In order to provide the child with adequate help, it is necessary to make a distinction between two basic types of this pathological state: flexible and rigid flat feet. A flexible flat foot, if it is not accompanied by any further problems, practically does not require treatment, while a rigid flat foot usually requires surgical treatment.

This research represents one in a series of studies with the aim of determining the factors of occurrence and prevalence of flat feet among preschool children. By reviewing the current research, it was determined that with an increase in age the prevalence of flat feet among children decreases. In addition, it was determined that one of the main factors of the occurrence of flat feet is obesity, as well as that this disorder occurs more often among boys. By applying adequate corrective treatment we can bring about a decrease in the prevalence of flat feet among preschool children. Physical activity is very important for the proper development of children of this age, and thus for a reduction in the risk of the occurrence of flat feet. 


\section{REFERENCES}

Aleksandrović, M., \& Kottaras, S. (2015). Does pes planus precondition diminish explosive leg strength: A pilot study. Facta Universitatis Series Physical Education and Sport, 13(2), 303-309.

Chen, J.P., Chung, M.J., \& Wang, M.J. (2009). Flatfoot prevalence and foot dimensions of 5-13 year-old children in Taiwan. Foot Ankle International, 30 (4), 326-332.

Chen, K.C., Yeh, C.J., Tung, L.C., Yang, J.F., Yang, S.F., Wang, \& C.H. (2011). Relevant factors influencing flatfoot in preschool-aged children. European Journal of Pediatrics, 170, 931-936.

Echarri, J.J., \& Forriol, F. (2003). The development in footprint morphology in 1851 Congolese children from urban and rural areas, and the relationship between this and wearing shoes. Journal of Pediatric Orthopaedics B, 12, 141-146.

Ezema, C.I., Abaraogu, U.O., \& Okafor, G.O. (2014). Flat foot and associated factors among primary school children: A cross-sectional study. Hong Kong Physiotherapy Journal, 32, 13-20.

Hsun-Wen, C., Chien-Ju, L., Li-Chieh, K., Ming-June, T., Hsiao-Feng, C., \& Fong-Chin, S. (2012). Threedimensional measurement of foot arch in preschool children. BioMedical Engineering, 11 (1), 76.

Jiménez-Ormeño, E., Aguado, X., Delgado-Abellán, L., Mecerreyes, L., \& Alegre, L.M. (2013). Foot morphology in normal-weight, overweight, and obese schoolchildren. European Journal of Pediatrics, 172(5), 645-652.

Karković, R. (1998). Roditelj i dijete u športu (Parents and children in sport). Zagreb: Oktar. In Croatian

Maksimović, N., \& Milošević, Z. (2008). Stil života mladih Vojvodine (The lifestyle of the youths of Vojvodina). Faculty of Sport and Physical Education, University of Novi Sad and Association for School Sports and Olympic Education of the City of Novi Sad. In Serbian

Mauch, M., Grau, S., Krauss, I., Maiwald, C., \& Horstmann, T. (2008). Foot morphology of normal, underweight and overweight children. International Journal of Obesity, 32, 1068-1075.

Mickle, K.J., Steele, J.R., \& Munro, B.J. (2006a). The feet of overweight and obese young children: Are they flat or fat? International Journal of Obesity, 14 (11), 1949-1953.

Mickle, K. J., Steele, J. R., \& Munro, B. J. (2006b). Does excess mass affect plantar pressure in young children?. Pediatric Obesity, 1(3), 183-188.

Mickle, K.J., Steele, J.R., \& Munro, B.J. (2008). Is the foot structure of preschool children moderated by gender? Journal of Pediatric Orthopaedics, 28(5), 593-596.

Mickle, K.J., Cliff, D.P., Munro, B.J., Okely, A.D., \& Steele, J.R. (2011). Relationship between plantar pressures, physical activity and sedentariness among preschool children. Journal of Science and Medicine in Sport, 14(1), 36-41.

Mihajlović, I., Šolaja, M., \& Petrović, M. (2010). Foot deformities in preschool children according to their gender and age. Glasnik Antropološkog društva Srbije, (45), 475-481.

Mihajlović, I., Smajić, M., \& Sente, J. (2010). Frequency of foot deformity in preschool girls. Vojnosanitetski Pregled, 67(11), 928-932.

Milošević, Z., Obradović, B., \& Srdić, B. (2007a). Status uhranjenosti devojčica starijeg školskog uzrasta (The nutritional status of older school age girls). In G. Bala (Ed.) Antropološki status i fizička aktivnost dece, omladine i odraslih (The anthropological satus and physical activity of children, youths and adults). pp 81-89. Faculty of Sport and Physical Education, University of Novi Sad. In Serbian

Milošević, Z., Obradović, B., Srdić, B. (2007b). Status uhranjenosti dečaka starijeg školskog uzrasta (The nutritional status of older school age boys). In G. Bala (Ed.) Antropološki status i fizička aktivnost dece, omladine i odraslih (The anthropological satus and physical activity of children, youths and adults). pp 9097. Faculty of Sport and Physical Education, University of Novi Sad. In Serbian

Moher, D., Liberati, A., Tetzlaff, J., \& Altman, D. G. (2009). Preferred reporting items for systematic reviews and meta-analyses: the PRISMA statement. Annals of Internal Medicine, 151(4), 264-269.

Mueller, S., Carlsohn, A., Mueller, J., Baur, H., \& Mayer, F. (2016). Influence of obesity on foot loading characteristics in gait for children aged 1 to 12 Years. PloS One, 11(2), e0149924.

Protić-Gava, B. (2008). Frequency of impaired bodily posture in the BMI categories and its share according to gender. In S. Nădăban (Ed.). The International Symposium Research and Education in Innovation Era. Book of Proceedings, $2^{\text {nd }}$ Edition, (pp 559-564). Arad: Aurel Vlaicu University.

Pfeiffer, M., Kotz, R., Ledl, T., Hauser, G., \& Sluga, M. (2006). Prevalence of flat foot in preschool - aged children. Pediatrics, 118, 634-639.

Radisavljević, M. (2001). Korektivna gimnastika sa osnovama kineziterapije (Corrective gymnastics with an introduction to kinesitherapy). College for Sports Trainers, Belgrade. In Serbian 
Riddiford-Harland, D.L, Steele, J.R, \& Baur, L.A (2011a). Are the feet of obese children fat or flat? Revisiting the debate. International Journal of Obesity, 35, 115-120.

Riddiford-Harland, D.L., Steele, J.R., \& Baur, L.A. (2011b). Medial midfoot fat pad thickness and plantar pressures: are these related in children? International Journal of Pediatric Obesity, 6(3-4), 261-266.

Sallis, J.F., Prochaska, J.J., \& Taylor, W.C. (2000). A review of correlates of physical activity of children and adolescents. Medicine and Science in Sports and Exercise, 32(5), 963-975.

Sonia, J., Nadia, L., Manel, A., Samia, F., Mohamed, B. R., Walid, O., Afif, Z, \& Faycel, K. (2015). Children flat foot and lower limb rotational profile: A cross-sectional descriptive study. Open Journal of Orthopedics, 5(10), 326-335.

Stanišić, I.R., Đorđević, M.M., \& Maksimović, S.Z. (2014). Posturalni status nogu i svoda stopala kod dece predškolskog uzrasta i efekti korektivnog vežbnja u okviru usmerenih aktivnosti (The postural status of the feet and arches in preschool children and the effects of corrective exercise as part of the prescribed activities). Sinteze, 3 (5), 63-71. In Serbian

Vergara-Amador, E., Sanchez, R.F.S., Posada, J.R.K., Molano, A.K., \& Guevara, O.A. (2012). Prevalence of flatfoot in school between 3 and 10 years. Study of two different populations geographically and socially. Colombia Medica, 43 (2), 141-146.

Woźniacka, R., Bac, A., Matusik, S., Szczygieł, E., \& Ciszek, E. (2013). Body weight and the medial longitudinal foot arch: high-arched foot, a hidden problem? European Journal of Pediatrics, 172(5), 683-691.

Živković, D., \& Karaleić, S. (2014). Korektivna gimnastika (Corrective gymnastics). Faculty of Sport and Physical Education, University of Niš. In Serbian

Živković, D. (2009). Osnove kineziologije sa elementima kliničke kineziologije (Fundaments of the kinesiology with elements of clinical kinesiology). Faculty of Sport and Physical Education, University of Niš. In Serbian

\section{ČINIOCI KOJI UTIČU NA POJAVU I PREVALENCU RAVNIH STOPALA PREDŠKOLSKE DECE}

Stopalo predstavlja jedan od najkomplikovanijih anatomskih segmenata ljudskog tela. Filogenetski govoreći, kao "najmlađi organ homo erektusa", stopalo podleže različitim poremećajima $i$ deformitetima. Ravna stopala (pes planus) predstavljaju jedan od najčešćih deformiteta donjih ekstremiteta, sa karakteristikom gubitka normalnih fizioloških lukova. Predmet ovog istraživanja predstavlja učestalost ravnih stopala među predškolcima. Cilj ovog preglednog istraživanja jeste da identifikuje i sumira odgovarajuću literaturu o učestalosti ravnog stopala i o činiocima pojave ravnog stopala među predškolcima. Svi analizirani radovi objavljeni su u periodu od 2000. do 2016. godine. Rezultati istraživanja ukazuju na povećanu prevalenciju ravnih stopala sa otprilike 3 godine života, a smanjenju sa 6 godina. Glavni činioc pojave je gojaznost, a deformitet se javlja češće među dečacima. Zaključak je da bi se kontrolom telesne mase, dnevne fizičke aktivnosti, kao i adekvatnim korektivnim tretmanom mogli da smanje prevalencija deformiteta ravnih stopala dece predškolskog uzrasta.

Ključne reči: ravna stopala, deformitet, gojaznost, predškolski uzrast 